\title{
The Influence of Guided Inquiry Learning Strategies and Learning Motivation on the Outcomes of Islamic Education Learning in SMP Negeri 2 Bireuen
}

\author{
Tien Rafida ${ }^{1}$, Evi Idayani ${ }^{2}$ \\ ${ }^{1,2}$ Faculty of Tarbiyah and Teacher Training, Universitas Islam Negeri Sumatera Utara, Indonesia \\ titinrafida@gmail.com
}

\begin{abstract}
The purpose of this research was to determine: (1) the effect of the implementation of guided inquiry learning strategies on the learning outcomes of Islamic Religious Education, (2) the effect of learning motivation on learning outcomes of Islamic Religious Education, and (3) the interaction of learning strategies and learning motivation on learning outcomes of education. Islam. The research was conducted at SMP Negeri 2 Bireuen. This type of research is a quasi experiment. The study population was all students of class VIII spread over 6 classes. The sampling technique used was cluster random sampling. The data collection instruments were questionnaires and tests. The data analysis technique used was two-way analysis of variance in the $\alpha=0.05$ test. The results showed: (1) there was an effect of the implementation of guided inquiry learning strategies on student learning outcomes of Islamic Religious Education. In this case the learning outcomes of students who are taught with guided inquiry learning strategies are higher than the learning outcomes of Islamic Religious Education students taught with expository strategies. (2) there is an influence of learning motivation on students' learning outcomes of Islamic Religious Education, in this case the learning outcomes of students with high learning motivation are higher than the learning outcomes of Islamic Religious Education students with low motivation, and (3) there is an interaction between learning strategies and motivation. learning about student learning outcomes of Islamic Religious Education.
\end{abstract}

Keywords

guided inquiry, learning motivation

\section{Introduction}

Islamic religious education has an important position in shaping the character of the nation. Islamic Religious Education does not only teach knowledge about religion, but can direct students to become human beings who truly have strong religious qualities. For this reason, it is hoped that it can create an optimal teaching and learning process by managing learning well. Learning management is an activity that aims to activate students in the teaching and learning process carried out on the interaction between teachers and students. The implementation of the learning carried out includes three aspects, namely: cognitive, effective and psychomotor. When it is related to material in Islamic Religious Education, it means that a student must have knowledge of his / her religion, behave and behave as taught and practice what is ordered and leave all prohibitions from the religion they profess. To achieve this goal, in the learning implementation system in schools, teachers need to increase their creativity in learning. Because, the implementation of a good teaching and learning process will affect the learning process and student learning 
outcomes itself. Islamic religious education has an important position in shaping the character of the nation. Islamic Religious Education does not only teach knowledge about religion, but can direct students to become human beings who truly have strong religious qualities. For this reason, it is hoped that it can create an optimal teaching and learning process by managing learning well. Learning management is an activity that aims to activate students in the teaching and learning process carried out on the interaction between teachers and students. The implementation of the learning carried out includes three aspects, namely: cognitive, effective and psychomotor. When it is related to material in Islamic Religious Education, it means that a student must have knowledge of his / her religion, behave and behave as taught and practice what is ordered and leave all prohibitions from the religion they profess. To achieve this goal, in the learning implementation system in schools, teachers need to increase their creativity in learning. Because, the implementation of a good teaching and learning process will affect the learning process and student learning outcomes itself.

Based on the problems that occur during the learning process, you should immediately get attention, one of which is by using learning strategies that are suitable for student motivation so that learning outcomes increase. Implementing various learning strategies, the teacher can choose the appropriate strategy to achieve certain learning objectives and in accordance with the learning environment. One of them is by offering inquiry learning strategies. According to Wina Sanjaya (2008:196) the inquiry strategy is a series of learning activities that emphasize critical and analytical thinking processes to seek and find answers to a question in question. It is hoped that by seeking and finding their own knowledge, students will better understand the concepts in the material. Confirming this opinion Gulo (2004: 84) explains that inquiry learning is a series of learning activities that involve students actively seeking and investigating systematically, critically, logically, analytically, so that they can formulate their own findings confidently. So there are three things that are important from inquiry learning, namely student involvement, activity direction and developing self-confidence.

In learning with inquiry learning strategies students see the learning process as a skill that they can use to be more curious about everything in this world, see the teacher as a facilitator asking more questions, where the questions are used to develop activities and material, skilled in proposing cause and effect from observations and full of pure ideas (Hidayat, 1996). The inquiry learning strategy emphasizes students to be more skilled in the learning process so that the learning activities experienced by students are not monotonous so that students are more motivated in the learning process, especially in learning Islam. With the use of inquiry strategies in the learning process of Islam, the teacher expects students to be more motivated in the teaching and learning process and their learning outcomes will increase. Zarkasyi (2020) stated that Islamic education is the traits or things that are inherent in Islamic education that ar used as a basis for humans to achieve the goals of human life that is serving Allah SWT based on the Islamic Teachings of the Qur'an and Sunnah so that the realization of our human beings after the education process is over.

Sanjaya (2008: 202) explains the syntax of inquiry learning includes: orientation, formulating problems, formulating hypotheses, collecting data, testing hypotheses, and formulating conclusions. Meanwhile, Sagala (2006: 197-198) reveals the steps of learning with guided inquiry, the syntax is as follows: (1) students formulate problems to solve, (2) students propose hypotheses, (2) students seek information / data information to answer hypothesis, (3) students draw conclusions, and (4) students apply the conclusions in new situations. 
Motivation to learn is a change in energy within a person (personal) which is marked by the emergence of feelings and reactions to achieve goals (Frederick J. Mc Donald in $\mathrm{H}$. Nashar, 2004: 39). But according to Clayton Alderfer in H. Nashar (2004: 42) Motivation to learn is the tendency of students to carry out learning activities that are driven by the desire to achieve the best possible achievement or learning outcomes. Kuswati (2019) motivation is the process of giving motives, encouragement, or stimulation to subordinates so that they want to work consciously and sincerely as well as have passion in the effort to achieve organizational goals.

Hamalik (2003: 161) also suggests three motivational functions, namely; (1) encourage behavior or an act. Without motivation, there will be no action such as learning, (2) motivation functions as a guide. This means moving the action towards achieving the desired goal, (3) motivation functions as a driving force. This motivation functions as a machine, the size of the motivation will determine whether a job or an action is slow or fast. Mc.Donald in Sardiman (2010: 73) states that the indicators of learning motivation are: (1) hope for success in learning, (2) desire to learn, (3) encouragement to succeed, and (4) enthusiasm for achievement.

\section{Research Methods}

The research method used is a quasi experiment (pseudo experiment) which aims to determine the effect of guided inquiry learning strategies and learning motivation on learning outcomes of Islamic Religious Education. using a 2 × 2 factorial design. The study population was all students of class VIII spread over 6 classes. The sampling technique used was cluster random sampling. Data collection techniques were questionnaires and learning outcomes tests, with the data analysis technique used was two-way analysis of variance.

\section{Results And Discussion}

The results of testing the first hypothesis show that the learning outcomes of students taught with guided inquiry learning strategies are higher than students taught with expository learning strategies, with an average learning outcomes of guided inquiry learning strategies ( $\bar{X}=70.93$ ) while in expository learning strategies ( $\bar{X}=69.69$ ).

This shows that the guided inquiry learning strategy is proven to be effective in improving the learning outcomes of Islamic Religious Education. The results of these findings indicate that to teach Islamic Religious Education teaching materials it is more appropriate to use guided inquiry learning strategies than with expository learning strategies. This is because inquiry learning is based on the constructivist learning theory developed by Piaget. According to Piaget as quoted by Sanjaya (2009:196), this knowledge will be meaningful if students seek and find it themselves. The knowledge obtained by self-discovery will have a good impact on students because this knowledge will last a long time so that it has an impact on better learning outcomes.

The same thing is emphasized by Sund and Trowbridge (1973: 67-72) that inquiry learning prepares situations for children to carry out their own experimental activities and seek answers to their own questions. According to Sund and Trowbridge, there are three kinds of inquiry approaches, namely: free inquiry, modified free inquiry and guided inquiry. 
The explanation above is in line with Wena's (2009) explanation of guided inquiry learning strategies aimed at developing students' knowledge and skills in exploring multicomplex symptoms. Furthermore, Wena (2009) explains that: (1) guided inquiry learning strategies are designed to improve students 'abilities and skills in solving problems, (2) several research results show that guided inquiry learning strategies are proven to be effective in improving students' abilities and skills in solving problems. problems, and (3) the guided inquiry learning strategy is a synchronization between teaching theory and learning theory which has a systematic procedure and is easy to implement by the teacher.

Guided inquiry learning strategies can encourage students to actively learn because students can seek various information and various sources. In addition, the guided inquiry learning strategy aims to foster student participation in solving issues or problems raised by the teaching staff in learning, fostering discussion among students in finding causes and solutions to the issue or problem. Therefore the role of the teaching staff in guided inquiry learning is as a facilitator who directs students to construct their own knowledge.

Teachers are expected to have the ability to create a fun and meaningful learning atmosphere. To create a fun and meaningful atmosphere is not easy. Therefore we need knowledge and skills on how to create a pleasant and meaningful classroom atmosphere. One of them is the use of appropriate learning strategies. The use of learning strategies cannot be separated from the characteristics of students. Because if the teacher knows the characteristics of each student, the teacher will know the appropriate learning strategy to use. If the teacher can apply learning strategies appropriately and know the characteristics and needs of students, it can improve student learning outcomes.

The findings of this study support the findings of previous research conducted, including: (1) research by Falahuddin et al. (2016) shows that guided inquiry learning gets a positive response with very agreeable responses from students. It is concluded that the guided inquiry learning model on environmental management material affects the critical thinking skills of students at SMP Negeri 2 Tanjung Lago, Banyuasin Regency, (2) Sumarni's research (2017) shows that there are differences in cognitive learning outcomes from guided inquiry models that are better than the model. conventional learning with an effect of 29.49 percent, and (3) Iswatun's research (2017) shows that the increase in the experimental class, both KPS and cognitive learning outcomes, is higher than the control class. The results of the Pearson correlation test show that KPS has a positive effect on student cognitive learning outcomes with the output correlation = 0.554 .

Furthermore, if it is further noted that in the guided inquiry learning strategy learning, the average learning outcomes of Islamic Religious Education with high learning motivation $(\bar{X}=75.00)$ are higher than those of students with low learning motivation ( $\bar{X}=64.92)$. $)$.

Whereas in the expository learning strategy, the average learning outcomes of Islamic Religious Education students with high learning motivation ( $\bar{X}=71.77$ ) were higher than the learning outcomes of students with low learning motivation $(\bar{X}=69.10)$. This shows that learning motivation is significant to differentiate student learning outcomes of Islamic Religious Education, where students with high learning motivation are better taught with guided inquiry learning strategies, while students with low learning motivation are better taught with expository strategies. 
The second hypothesis testing shows that the learning outcomes of students with high learning motivation are higher than students with low learning motivation. These results prove that learning motivation in learning is significant for differentiating learning outcomes. The motivation to learn in this study is categorized into two categories, namely high and low. From the results of data analysis as a whole, it was obtained that the average learning outcomes of Islamic Religious Education students with high learning motivation $(\bar{X}=73.42)$ were higher than those of students with low learning motivation $(\bar{X}=67.80)$. This indicates that students with high learning motivation on average have better learning outcomes of Islamic Religious Education than students with low learning motivation. Thus students with high learning motivation better understand and master the teaching material than students with low learning motivation.

This shows that learning motivation is significant enough to differentiate student learning outcomes, where the learning outcomes of students with high learning motivation, both those taught by collaborative learning strategies and competitive learning strategies are better than the learning outcomes of students with low learning motivation.

The role of motivation with student success in learning is very close and inseparable. The higher the learning motivation of a student, the greater the effort he will make to achieve his learning success. Because motivation in a person becomes a driving force (motor) that will activate all available energies, including learning activities. Thus, it can be stated that learning motivation has a positive and significant relationship with student learning outcomes.

Clayton Alderfer as quoted by Nashar (2004:42) learning motivation is an internal and external drive that causes a person (individual) to act or achieve goals, so that behavior changes in students are expected to occur.

This is in line with Hamalik's (2004: 161) explanation which states that the function of motivation is: (1) encouraging behavior or deeds. Without motivation there will be no action, for example learning, (2) motivation functions as a guide, meaning directing actions to achieve the desired goal, and (3) motivation functions as a driving force, meaning moving one's behavior. The size of this motivation will affect how quickly a job / task can be completed properly.

Students in implementing learning have different learning motivation from one another. But certainly, every student desires to be able to achieve high learning outcomes and have beneficial values in life. Therefore, every student has the motivation that is directed and encourages him to do something with all the abilities he has. With the existence of motivation can be a driving force to carry out learning activities to the fullest.

Students want to do a learning activity with all the effort they have, because in a person there is such great strength and energy. Therefore, motivation is the psychological aspects that are owned by each individual. Motivation is a force (power), power (energy), or a complex state (a complex state) and readiness (preparatory set) within the individual (organism) to move (to move, motion, motive) towards a specific goal, whether consciously or unconsciously.

The teacher has a role to always develop students' motivation to learn optimally in the learning process. Because in each student there is stored power, forces, energy, or a complex state and a preparatory set within the individual (organism) to move (motion, motive) to carry out their learning activities. 
The position of motivation with a student's success in learning is very close and inseparable. The higher the learning motivation of a student, the greater the effort he will make to achieve his learning success. Because motivation in a person becomes a driving force (motor) that will activate all the available energy, including learning activities. Thus, it can be stated that learning motivation has a positive and significant relationship with student learning outcomes.

The findings of this study are in line with previous research conducted including: (1) Warti (2016) who found that there was a positive influence between student learning motivation and student mathematics learning outcomes. With the regression equation $\mathrm{Y}=$ $a+b x=29.65+0.605 x$. The correlation coefficient $r=0.974$ is significant at $\alpha=0.05$, and (2) the research of Nurdin (2015) teachers of SMAN 1 Bandung shows that learning motivation has a relationship with learning citizenship education of students of SMAN 1 Bandung. The coefficient of determination (R2) of 0.504 means that $50.4 \%$ learning motivation has a relationship with civic education learning achievement, while the remaining $49.6 \%(100 \%-50.4 \%)$ is influenced by other factors.

Testing the third hypothesis there is an interaction between learning strategies and learning motivation in influencing student learning outcomes of Islamic Religious Education. When seen the average learning outcomes of Islamic Religious Education in students with high learning motivation who are taught with guided inquiry learning strategies $(\bar{X}=75.0)$ are higher than the average learning outcomes of students with high learning motivation who are taught with expository strategies $(\bar{X}=71.77)$.

Then the average learning outcomes of Islamic Religious Education in students with low learning motivation who are taught with guided inquiry learning strategies $(\bar{X}=$ 64.92) are lower than the average learning outcomes of students with low learning motivation who are taught with learning strategies expository $(\bar{X}=69.10)$.

The results of these findings indicate that to teach Islamic Religious Education teaching materials it is more appropriate to use guided inquiry learning strate gies than with expository learning strategies. This is in line with Wena's (2009) explanation of guided inquiry learning strategies aimed at developing students' knowledge and skills in exploring multicomplex symptoms.

The learning outcomes of students with high learning motivation who are taught with guided inquiry learning strategies are significantly different from those taught with guided inquiry learning strategies at a price of $\mathrm{F}_{\text {count }}=7.17>\mathrm{F}_{\text {table }}=2.688$ with an average learning outcome of Islamic Religious Education students with high learning motivation who were taught using guided inquiry learning strategies $(\bar{X}=75.00)$ were higher than students with low learning motivation who were taught with guided inquiry learning strategies $(\bar{X}=64.92)$.

The learning outcomes of Islamic Religious Education students with high learning motivation who are taught with guided inquiry learning strategies are significantly different from the learning outcomes of Islamic Religious Education students with low learning motivation who are taught with expository learning strategies, at a price of $\mathrm{F}_{\text {count }}$ $=5.29>\mathrm{F}_{\text {table }}=2.688$, with The average learning outcomes of students with high learning motivation who were taught using guided inquiry learning strategies $(\bar{X}=$ 75.00) were higher than students with low learning motivation who were taught using expository learning strategies $(\bar{X}=69.10)$.

The learning outcomes of students with high learning motivation who are taught with expository learning strategies are significantly different from the learning outcomes of students with low learning motivation who are taught with guided inquiry learning 
strategies, at a price of $\mathrm{F}_{\text {count }}=4.02>\mathrm{F}_{\text {table }}=2.688$, with an average The learning outcomes of students with high learning motivation who are taught using expository learning strategies $(\bar{X}=71.77)$ are higher than students with low learning motivation who are taught using guided inquiry learning strategies $(\bar{X}=64.92)$.

The learning outcomes of students with high learning motivation who are taught with expository learning strategies are not significantly different from those taught with expository learning strategies, with a price of $\mathrm{F}_{\text {count }}=1.85<\mathrm{F}_{\text {table }}=2.688$, with an average student learning outcomes of Islamic Religious Education with High learning motivation taught using expository learning strategies $(\bar{X}=71.77)$ was higher than students with low learning motivation who were taught using expository learning strategies $(\bar{X}=69.10)$.

The learning outcomes of students with low learning motivation who are taught with guided inquiry learning strategies are not significantly different from those taught with expository learning strategies, with a price of $\mathrm{F}_{\text {count }}=3.24>\mathrm{F}_{\text {table }}=2.688$, with an average student learning outcomes of Islamic Religious Education. with low learning motivation taught using guided inquiry learning strategies $(\bar{X}=64.92)$ lower than students with low learning motivation who were taught using expository learning strategies $(\bar{X}=69.10)$.

\section{Conclusion}

The conclusions that can be drawn from the research findings are as follows: (1) there is an effect of the implementation of guided inquiry learning strategies on the learning outcomes of Islamic Religious Education, in this case the learning outcomes of students being taught with guided inquiry learning strategies are higher than the expository strategy. 2) there is an influence of learning motivation on learning outcomes of Islamic Religious Education, in this case the learning outcomes of students with high learning motivation are higher than students with low learning motivation, and (3) there is an interaction between learning strategies and learning motivation on learning outcomes of Religious Education Islam.

Recommendations that can be given are: (1) teachers are advised to implement guided inquiry learning strategies that are appropriate for Islamic Religious Education teaching materials because through this research it is proven that guided inquiry learning can improve learning outcomes of Islamic Religious Education, (2) teachers are advised to see characteristics of student learning motivation in applying guided inquiry and expository learning strategies. For students with high learning motivation it is more appropriate to be taught with guided inquiry learning strategies, while for students with low learning motivation, the learning strategy that is more appropriate to apply is expository learning strategies, (3) students are advised to continue to maintain and increase their learning motivation, and (4) ) to other researchers who want to investigate further about guided inquiry learning strategies, they should pay attention to other variables, especially those related to student characteristics such as learning styles, initial abilities, cognitive styles and so on so that more comprehensive knowledge is obtained. 


\section{References}

Falahuddin, Irham Dkk (2016). Pengaruh Model Pembelajaran Inkuiri Terbimbing Terhadap Kemampuan Berpikir Kritis Siswa Pada Pembelajaran Materi Pengelolaan Lingkungan Di Smp Negeri 2 Tanjung Lago, Kabupaten Banyuasin. Jurnal Bioilmi Vol. 2 No. 2 Agustus 2016.

Hamzah B. Uno. (2007). Model Pembelajaran Menciptakan Proses Belajar Mengajar yang Kreatif dan Efektif. Jakarta: Bumi Aksara.

Iswatun dkk (2017) Penerapan Model Pembelajaran Inkuiri Terbimbing untuk Meningkatkan KPS dan Hasil Belajar Siswa SMP Kelas VIII. Jurnal Inovasi Pendidikan IPA, 3 (2), 2017.

Kuswati, (2019). Motivation Role in Improving Work Effectiveness. Budapest International Research and Critics Institute-Journal (BIRCI-Journal). P. 281-288.

Nurdin (2015) Hubungan Motivasi Belajar Terhadap Prestasi Belajar Pendidikan Kewarganegaraan. Jurnal: Faktor Jurnal Ilmiah Kependidikan Vol. II No. 2 Juli 2015.

Oemar Hamalik. (2003). Perencanaan Pengajaran Berdasarkan Pendekatan Sistem. Jakarta: Bumi Aksara.

Oemar Hamalik.(2008). Proses Belajar Mengajar. Jakarta: Bumi Aksara.

Rusydi Ananda. Perencanaan Pembelajaran. Medan: LPPPI, 2019.

Sardiman, A. M. (2011). Interaksi dan Motivasi Belajar Mengajar. Jakarta: Raja Grafindo Persada.

Sumarni, dkk (2017). Pengaruh Model Pembelajaran Inkuiri Terbimbing Terhadap Hasil Belajar Kognitif Peserta Didik Di Sma Negeri 01 Manokwari (Studi Pada Pokok Bahasan Kelarutan Dan Hasil Kali Kelarutan. Jurnal Nalar Pendidikan Volume 5, Nomor 1, Jan-Jun 2017.

Warti, Elis.(2016) Pengaruh Motivasi Belajar Siswa terhadap Hasil Belajar Matematika Siswa di SD Angkasa 10 Halim Perdana Kusuma Jakarta Timur. Jurnal: Mosharafa, Pendidikan Matematika STKIP Garut, Volume 8, Nomor 3, April 2016.

W. Gulo. (2002). Strategi Belajar Mengajar. Jakarta: Grasindo.

Wina Sanjaya. (2008). Kurikulum dan Pembelajaran. Jakarta: Kencana Media Group.

Zarkasyi, et al. (2020). Internalization of Islamic Religious Education Values in Scouting Extracurricular Activities in Forming Student Character in Public Middle School 2 Peunaron East Aceh. Budapest International Research and Critics Institute-Journal (BIRCI-Journal). P. 838-848. 